\title{
Neologisms Concerning Migration Processes: A Czech Example
}

\author{
Tena Šinjori*
}

\begin{abstract}
In order to describe changes in the lexical system, M. Dokulil used the metaphor of a deep body of water. While down in the deep, nothing is happening, on the surface the water never stops to move, flow, circulate. In Dokulil's metaphor, the surface layer symbolises those lexical items closely related to social changes: new words and old words whose meaning has changed, or old words that have become elements of new words.

The analysis of neologisms occurring during relevant social changes provides a valuable insight into the users' attitudes towards contemporary events. This paper deals with neologisms and neosemanticism concerning the migration processes that have taken place in Europe from 2011 to 2018. The neologisms are extracted from Neomat, the database for Czech neologisms. An analysis based on word formation and semantics, supported by papers in Neologizmy v dnešni čestinèe, is followed by an analysis from a sociolinguistic perspective, relying on the work of V. Dvořáčková, E. Mleziva and the theoretical frame given in the monography of V. Muhvić-Dimanovski.

The focus of this article will be on those words which denote concepts related to the great migrations of our time. The productive formation by employing prefixes meaning pro or contra indicates a social urge to express polar attitudes on the subject. Due to the relevance of migration processes in a global context, lexical and semantical borrowing
\end{abstract}

\footnotetext{
* Faculty of Humanities and Social Sciences, University of Zagreb; tsinjori@ffzg.hr
} 
constitute the most frequent word formation types. The meaning of some stable lexical items has changed due to an increased frequency of use and this is carried out in two opposite ways: by blurring lines between closely related items and by filling empty spaces in order to gain higher levels of precision.

Key words: Neologisms, Czech language, Sociolinguistics, Migration, Refugees

\section{Introduction}

In her work, Lišková (2018) takes into account papers concerning neologisms and establishes seven criteria of definition: the existential criterion, the criterion of time, the lexicographic criterion, the psychological criterion, the structural criterion, the criterion of variety and the criterion of stability or instability (Lišková 2018,48). The criterion of time is the most prominent and present in all works dealing with the subject of neologisms and, because of that, the definition of new words is primarily based on it. For the purpose of our paper, we use the definition formulated by Muhvić-Dimanovski (2005), stating that neologisms are new elements of the lexical system which rise in a language to fulfil three aims: to name new things and phenomena, to express new affective, stylistic, or pragmatic nuances of already stable lexical items, and to reflect specific political (or other) circumstances (Muhvić-Dimanovski 2005, 4). The rise of neologisms is thus a linguistic response to recent social events. The deep connection between neologisms and society is visible on different levels of language structure: morphological, syntactical, semantical, and pragmatic.

By virtue of this connection, neologisms display a great expressive power in their structure, revealing important information about the spirit of contemporary times. In this paper, we consider the neologisms in the Czech language that arose as a result of the migration processes in Europe during the last decade (since the beginning of the Arab Spring in 2011) in relation to word formation, semantics, and pragmatics. Following a sociolinguistic approach, we aim to discover the ways in which social facts on the subject of migration are being reflected in the language and in which way the structure of new words can provide information on the speakers' attitudes towards the topic. It is important to stress that the aim of this paper is neither to classify nor to analyse all neologisms concerning migration. The main purpose is to detect the most productive word formation processes and morphological characteristics of lexical items which can be related to the social context of migration processes. Special attention is devoted to pragmatic features, particularly to the speaker's attitude towards the subject of migration. 
It is assumed that many excerpted neologisms associated with migration in the Czech language contain elements loaned from other languages, given that the subject is being discussed on a global level. Another reason for this assumption is that the material for the Czech neologism database was mostly taken from newspaper articles that were in some cases translated from other languages. The second hypothesis is that, among neologisms, some lexical items will occur which are already stable in the lexical system, but whose scope of meaning has changed due to the relevance of the topic and the increased frequency of use. The meaning of those lexical items is presumably going to be dissected and some empty spaces will be filled to allow for more precise expressions.

Nevertheless, the opposite process is also expected: due to the increased frequency of use of lexical items associated with migration in everyday public discourse, differences between some closely related concepts will be blurred in their everyday use. The last hypothesis is that many neologisms are going to be pragmatically (emotionally, stylistically, evaluative) marked.

The expected significance of this paper is to provide an insight into the ways social processes connected to migration from 2011 to 2018 inscribe themselves in language and, on the other hand, what the structure of words related to processes of migration can tell us about the perception of social processes among the speakers of a given language. After the Introduction, the theoretical basis providing the inspirational model for this research will be presented. The Methodology will be treated in the following section. The analytical part of the paper is divided into four subchapters according to four analysed parts of speech. The outcomes of the analysis and the Conclusion will be presented in the last chapter.

\section{Theoretical Framework}

Intensive research in Czech neology started being undertaken after the founding of the lexical archive Neomat, edited by the Department of Contemporary Lexicology and Lexicography of the Czech Language Institute. The materials collected in Neomat constituted the basis allowing the publishing of two dictionaries of neologisms: Nová slova v češtinè. Slovnik neologizmů 1 (1998) and Nová slova v čestinè. Slovnik neologizmü 2 (2004). Both dictionaries were edited by O. Martincová who dedicated much of her career to the field of neology. One of her works, the edited book Neologizmy v dnešni čestinè (2005) served as support material for the analysis of word formation and semantic features of neologisms in this paper (Ústav pro jazyk český 2011). 
Sociolinguistic research projects of Czech neologisms were launched in more recent years, and many of them were induced by the Czech Republic's entry to European Union (see, for example, Jítková (2005), Šimandl (2013)). Especially inspiring for this paper was the work of V. Dvořáčková about neologisms in Dodatky (Supplements) to the monolingual dictionary Priručni slovnik jazyka čskébo. Some of the words she uses as examples were never published in the dictionaries due to the changes of the political climate. Dvořáčková states that those words can function as reflections of changes in society and also as good examples of political influence on the lexical layer in a certain language. Using examples such as černoprdelnik (a man having black buttocks) Dvořáčková is trying to draw correlations between language and society: naming a member of Church hierarchy as črnoprdelnik is explanatory of the attitude of society and mainstream politics of the time towards the Church (Dvořáčková 2013). Consequently, such examples provide a good basis for examining neologisms as sources of information on speakers' attitudes.

\section{Methodology}

Monolingual dictionaries of the Czech Language cited in the reference list were consulted in order to identify lexical items denoting refugees. The following words were chosen:

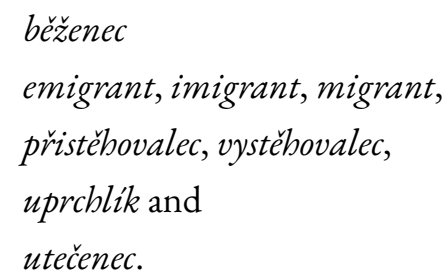

Root morphemes (allomorphs included) of listed words were traced in the Neomat database by using truncation: ${ }^{*}$ root*, for example: ${ }^{*}$ migr* . The date was set as $>=$ January 1, 2011, the beginning year of the Arab spring which caused recent large-scale migrations and events labelled as migration crisis in 2015 (Tadić, Dragović, and Tadić 2016). The results for each root are restricted one more time by using the filter Hesla neosemantická (neosemantic expressions) in order to detect neosemanticisms. The obtained lists of words are being reviewed in order to extract words which occurred on the list accidentally (because of the same root as the source words, e. g. sprchovack a (colloquial expression for "taking a shower") for *prch* which is the root of uprchlik (refugee). The 
“purified” lists were grouped according to word classes. Lexical items were analysed according to word formation and semantic features. The sociolinguistic analysis included the observation of these words in a specific context. In addition to this, words with expressed pragmatic features were taken into special consideration.

\section{Analysis}

The analysis revealed 63 words recognised as neologisms, $49 \%$ of which were adjectives, $27 \%$ nouns, $14 \%$ adverbs, and $10 \%$ verbs. Nine words (14\%) were marked as neosemanticism.

\subsection{Nouns}

Nouns are formed in two ways: by prefixation using both prefix and root of foreign origin: antiimigrace (antiimmigration); both prefix and root of domestic origin: priprchlik (pri means "closer to", prchat means "to flee, to run away"). Compounds are formed in various ways, the first element being of domestic and the second of foreign origin: běžencofil (the one that sympathizes with refugees), Uprchlistán (Refugeestan); the first element of foreign and the second of domestic origin: migrantožrout (migrantvore). Two examples of univerbation typical for common Czech and colloquial varieties occurred: emigračka standing for prípad emigrace (a case of emigration), uprchličák standing for uprchlický tábor (refugee camp). The majority of nouns (65\%) denotes a person, the rest marks places (uprchličák, Uprcblistán) and abstract concepts (antiimigrace).

From a lexicological point of view, the word priprchlik is very interesting because it is a relational antonym of the stable lexical item uprchlik (refugee). The creation of an opposite word by exchanging prefix $u$ - (moving away) with prí- (coming closer) implies the fact that the direction of moving is emphasised: migration is viewed from the perspective of the people living in the country migrants are moving to. The meaning of the old lexical item uprcblik is narrowed, and therefore the new possible marker of a "migrating person" occurred within the realm of the same root. The new definition is dependent on the point of view. The speaker from whose utterance the word was excerpted in the database defines it as follows: "[Priprchlici?] Those who are in search of a better life. ${ }^{1}$ "There is only one blend among nouns: krimigrant (crimigrant). It is mentioned here because of its context. The author of the comment to a newspaper article

1 “Připrchlíci? To jsou ti, kteří prchají za lepším.” 
about a fire in a refugee camp explains the cause of this event: "Crimigrants were bored or cold. It is also done by the Gypsies, they move out and scream that they want new homes." ${ }^{2}$ Great affective power have the calques migrantožrout (confirmed in English and French as "migrantvore") and Uprcblistán (confirmed in German "Flüchtlingstan" and English "Refugeestan"), as well as the compound běžencofil (a person sympathizing with refugees) which was used with a sarcastic tone.

Lexical items which are already stable in the lexical system occur in the Neomat database either as a part of a collocation or as neosemanticisms. The form of the collocation ekonomicky migrant (economic migrant) foreshadows the status of the term, but its meaning is still not stable, as it depends on the context. One of the speakers defines it as "the one that would die or is hungry in his own country" 3 and distinguishes the collocation from the common Czech phrase jit za lepsim "in search of a better life". Other speakers define the collocation as "to be in search of a better life". Three collocations containing migrant as an element have gone through a process of phraseologisation: amenitni migrant (amenity migrant), zelený migrant (green migrant) and požitkový migrant (a person migrating for pleasure). All three are denoting people who undertake inner (town village) migrations in order to reach a better quality of life. The motivation behind the collocation digitalni pristéhovalec (digital migrant) is not completely transparent either. It stands in opposition to digitalni domorodec (digital native) and indicates a person who gained digital literacy in later phases of his or her life. The word uprcblik (refugee) also gained a new meaning. In cycling terminology, it defines a member of a peloton who has distanced himself from the rest of the group.

\subsection{Adjectives}

The majority of adjectives is formed by multiple processes, by using prefixes and suffixes: as for example in antiběženecký (antirefugee). Compounding is confirmed in the formation of complex adjectives such as muslimsko-migrantský (muslim-migrant).

There are several possible combinations of elements building adjectives which are formed by multiple processes: foreign prefix and domestic word base: antiběženecký (antirefugee); both foreign prefix and word base: antiimigrantský (antiimmigrant); both domestic prefix and word base: protiběženecký (antirefugee); domestic prefix and foreign base: protimigrantsky (antimigrant). In complex adjectives, the second part of the compound is always of foreign origin and the first part can be both of domestic and foreign

\footnotetext{
2 “Krimigranti se nudili nebo jim byla zima. To dělají cikání také, vybydlí a řvou, že chtějí nové."

3 “Za ekonomického migrant považuji toho, kdo ve své zami umírá nebo nemá dost jídla”
} 
origin: bezpečnostně-migračni (precautionary-migrant); populisticko-protiimigračni (populistic-antiimmigrant).

The complex adjective uprchlicko-imigrantsky (refugee-immigrant) does not take the origin of such elements into account. The first element is of Czech and second of Latin origin. The adjective emigrantský (opposite of imigrantský) in Czech is common in use and earlier in this paper the new word priprchlik (relational antonym of uprchlik) was mentioned. While not constructing the word *uprcblicko-pripprcblický is not significant (as long as priprchlik is not settled in lexical system), not constructing ${ }^{*}$ imigrantskoemigrantský is significant and it shows creativity and freedom in word formation.

From a semantic point of view, most adjectives express attitudes pro et contra by using appropriate prefixes: proimigračni - antiimigračni; prouprcblický - antiuprchlický - protiuprcblický; antiimigrantský - protiimigrantský - proimigrantský. An analysis of utterances containing adjectives in hyponymy relationships reveals that authors and speakers do not distinguish between the concepts of migration - immigration, and migrant - immigrant. The pairs of adjectives listed below are consequently used as synonyms. Close context is provided for each adjective.

1. promigračni - proimigračni

a. "opustí svưj post, pokud bude naše země promigrační" (he is going to leave his job if our country becomes promigrant)

b. "Pozval jsem kolegyně z př́slušného výboru EP z „proimigračních“ zemí typu Švédska a dalších do ČR” (I invited colleagues from the corresponding committee of the EP from "proimmigrant" countries such as Sweden and others to the Czech Republic)

2. protimigračni - protiimigračni

a. "Nespokojení Sasové se ženou do náruče radikálům i protimigrační straně AfD (Alternativa pro Německo)" (Dissatisfied Saxons rush into the arms of the radicals and the antimigrant party AfD (Alternative for Germany)

b. "koalici budou tvořit tři strany: vedle Sipiläho Strany středu v ní zasedne zřejmě populistická a protiimigrační strana Finů” (the coalition will be formed by three parties: besides Sipilä’s Central Party, the populist and antiimmigrant party of Finns will certainly join it as well)

\section{3. protimigrantský - protiimigrantský}

a. "nejvíce proruskou stranou je zároveň protimigrantská a protimuslimská Alternativa pro Německo (Afd)" (the most pro-Russian party is the antimigrant and antimuslim Alternative for Germany (AfD) 
b. "V Dánsku protiimigrantská Dánská lidová strana deset let podporovala menšinovou vládu” (In Denmark, the antiimmigrant Denmark People's Party had been supporting the minority government for ten years)

There is only one neosemanticism confirmed among the adjectives: zmigrovaný. It denotes a user of the telecommunication network who changed his or her operator. Adjectives stand by the noun and determine it (ascribe some quality to it or define its relationship to some substance). Because of that, the semantic analysis of the adjectives was accompanied by a noun analysis. Below we provide examples which are significant from a sociolinguistic point of view. Adjectives with elements anti-, proti-, combined with nouns, create constructions in which adjectives describe attitudes and actions of political parties. In Neomat, those adjectives are part of the following constructions: protiběženecká problášeni (antirefugee proclamation), antiběženecký pragmatismus (antirefugee pragmatism), antiuprchlickévýroky (antirefugee statements), protipristébovalecképostoje (antirefugee stances). In a wider context, all those constructions serve to describe a way to gain sympathies of voters by expressing counter (im)migrant attitudes.

\subsection{Adverbs}

All extracted adverbs are motivationally related with adjectives (antiimigračnè, antiuprchlicky, protiimigraíni, ...) They contain both domestic and foreign elements which are mentioned in section 4.2 .

\subsection{Verbs}

New verbs are formed by prefixation: primigrovat (migrate to the proximity) or by aspect change: pristěbovávat se (to move closer). All used prefixes are of Czech origin: do-, prí-, roz-, se-. Prefixes do- and prí- mean "to come closer". Half of the extracted verbs are created through these prefixes. 


\section{Conclusion}

The presence among neologisms associated with contemporary migration processes of many elements loaned from other languages confirms the hypothesis stated in the introduction. Apart from the very productive derivation by using Greek and Latin prefixes (anti-, pro-), calqued compounds and blends are also confirmed. Lexical items, which are stable in the lexical system, such as migrant and uprchlik, gained new meanings. They became heads of collocations denoting concepts either closely (ekonomicky migrant) or distantly (uprcblik in cycling) related to migration. Increased complexity of semantic relations shown by the example of the new word priprchlik, as opposed to the already stable uprcblik, confirms that the system aspires to greater precision. At the same time, equating words from the same semantic field (migration and immigration, migrant and immigrant) indicates blurred lines between semantically related concepts and therefore proves the process of determinologisation: terms originating in the field of the social sciences became frequent in everyday use. As a result, their extension (understood as a set of phenomena they denote (Vuković 2013, 103)) became less defined. While there are many words formed by migrant and immigrant as a word base, there are almost no words containing emigrant as its element. Moreover, half of the extracted verbs were formed by prefixes which stand for "coming closer". It is therefore clear that a prerequisite for semantic changes is the speakers' general focus on the migrants' arrival to Europe, not to the process of migration (as moving out from some place and moving to another place).

Adjectives with elements pro et contra indicate the bigger social debate and an urge to express one's attitudes towards the topic. The context shows that words with the element contra are related mostly to political parties and commentators on social networks. Words with the prefix pro- are used by or ascribed to speakers from international associations. Antonyms such as běžencofil and migrantožrout also indicate the need to express one's attitude towards the subject and, more importantly, that these attitudes are binary - either pro or contra.

Further research should use enlarged corpuses and analyse the broader context of each neologism and neosemanticism in order to reveal whether processes elaborated in this paper occur regularly. The question that seeks further research is to what extent these processes are a result of language borrowing and to what extent they represent the reflection of the speakers' attitudes in Czech society. 


\section{References}

Dokulil, Miloš. 1951. "Nová skutečnost v zrcadle slovní zásoby češtiny.” Naše řeč 35 (7-8): 121-131.

Dvořáčková, Věra. 2013. "Neologický charakter hesel v Dodatcích k Přiručnimu slovniku jazyka českého.” In Problemi na neologijata v slavjanskite ezici, edited by D. Blagoeva, S. Kolkovska and M. Lišková, 323-30. Sofia: Prof. Marin Drinov Academic Publishing House.

Filiačová, Sylva. 2016. "Blendy v elektronickém neologickém archivu Neomat." Jazykovédnéactuality 3(3-4): 100-6. http://www.jazykovednesdruzeni.cz/JA16 34 .pdf. (Accessed 26 February 2019).

Havránek, Bohuslav, ed. 1989. Slovnik spisovného jazyka českého. Prague: Academia

Hujer, Oldřich, ed. 1935-1937. Přiručni slovnik jazyka českého. Prague: Academia. http://bara. ujc.cas.cz/psjc/. (Accessed 24 January 2019).

Jílková, Hana. 2005. “Eurosloženiny na cestě k eurojazyku.” Čaopis pro moderní fllologii 87 (1): $1-9$.

Lišková, Michaela. 2018. “Neologismus v lingvistickém, mediálním a běžném obrazu světa.” PhD diss., Univerzita Karlova.

Martincová, Olga, ed. 1998. Nová slova vecestině. Slovnik neologizmů 1. Prague: Academia.

Martincová, Olga, ed. 2004. Nová slova v čestině. Slovnik neologizmů 2. Prague: Academia.

Martincová, Olga, ed. 2005. Neologizmy v dnešní češtině. Prague: Academia.

Mitter, Patrik. 2003. "Poznámky ke složeným hybridním substantivům s prvním komponentem (členem) cizího původu v současné slovní zásobě.” Slovo a slovesnost 64 (4): 289-97.

Mleziva, Emil. 1996. "Vliv společenských změn na vznik nových významů a výrazů v českém jazyce.” Slovo a slovesnost 57 (4): 283-96. http://sas.ujc.cas.cz/archiv.php?art=3694. Accessed 26 February 2019.

Muhvić-Dimanovski, Vesna. 2005. Neologizmi: problem teorije i primjene. Zagreb: FF Press, Zavod za lingvistiku.

Šimandl, Josef. 2009. “Výraz „euro“ v českém jazyce: počátky užívání a výhledy.” https://www. zavedenieura.cz/cs/dokumenty/odborne-texty. (Accessed 26 February 2019).

Tadić, Jure, Filip Dragović, and Tonči Tadić. 2016. "Migracijska i izbjeglička kriza - sigurnosni rizici za EU.” Policija i sigurnost 25, no. 1: 14-42.

Ústav pro jazyk český. 2011. “Neologizmy v dnešní češtině.” Last Modified February 20, 2011. http://www.ujc.cas.cz/sd/publikace/knizni/lexikologie-odd-publikace/lexikologie-dalsi-pub likace/neologizmy-v-dnesni-cestine.html.

Vuković, Petar. 2013. Uvod u jezikoslovnu bohemistiku 1. Zagreb: FF Press. 